\title{
Matteo De Chiara, Adriano V. Rossi, Daniel Septfonds (éds.). Mélanges d'ethnographie et de dialectologie irano-aryennes à la mémoire de Charles- Martin Kieffer
}

\section{Thomas Jügel}

\section{(2) OpenEdition \\ Journals}

Electronic version

URL: http://journals.openedition.org/abstractairanica/50492

DOI: $10.4000 /$ abstractairanica. 50492

ISBN: 1961-960X

ISSN: 1961-960X

Publisher:

CNRS (UMR 7528 Mondes iraniens et indiens), Éditions de l'IFRI

\section{Electronic reference}

Thomas Jügel, "Matteo De Chiara, Adriano V. Rossi, Daniel Septfonds (éds.). Mélanges d'ethnographie et de dialectologie irano-aryennes à la mémoire de Charles-Martin Kieffer", Abstracta Iranica [Online], Volume 40-41 | 2019, document 5, Online since 30 December 2019, connection on 23 April 2021. URL: http://journals.openedition.org/abstractairanica/50492 ; DOl: https://doi.org/10.4000/ abstractairanica.50492

This text was automatically generated on 23 April 2021.

Tous droits réservés 


\title{
Matteo De Chiara, Adriano V. Rossi, Daniel Septfonds (éds.). Mélanges d'ethnographie et de dialectologie irano-aryennes à la mémoire de Charles-Martin Kieffer
}

\author{
Thomas Jügel
}

\section{REFERENCES}

Matteo De Chiara, Adriano V. Rossi, Daniel Septfonds (éds.). Mélanges d'ethnographie et de dialectologie irano-aryennes à la mémoire de Charles-Martin Kieffer. Paris, Association pour l'avancement des études iraniennes, 2018, 413 p. + dépliant. (Studia Iranica. Cahier 61)

1 The volume under review is dedicated to Charles-Martin Kieffer (1923-2015). It begins with two texts in memoriam that reveal exciting information about Kieffer's life and personality, followed by a selected bibliography of his works.

Various scholars have contributed to this book; the 16 contributions are devoted to several topics of Iranic studies that Kieffer worked on himself (eight in French, six in English, two in German).

3 Lora Arys offers valuable information on Ossetian burial customs, which are affected by the change of daily life. Her description makes Russian and Ossetic sources available to the francophone community. Another paper on customs is the study on bacha posh [lit.] "boy-dressing" in the modern Afghan society by Alessandra Fiorentini. This practice of considering a girl as a boy (at least until marriage) in families that do not have a son is of particular interest for gender studies.

4 Rémy Dor investigates the transition from "orature" to literature in Turkic-speaking societies, notably of Central Asia, and their relevance for a national identity. Evelin 
Grassi examines the language policies in Afghanistan and Tajikistan regarding the respective two official languages (Dari and Pashto in Afghanistan and Tajik and Russian in Tajikistan). She identifies changes in their status and the concomitant recognition by outsiders. The late Marjâne Kamal gives a geopolitical analysis of the province of Logar for modern-day Afghanistan and identifies the triggers for social change in its recent history. The contribution of the late Manfred Lorenz is an account of a journey to Kabul that he undertook in 1976 for his Pashto textbook, which was published 1979, 1982 and 2010.

Sabir Badalkhan investigates historical sources from the $17^{\text {th }}$ century about the emergence of the Brahui confederation (or Brāhōī, previously called 'Kurdī/Kurdgālì'), also adding information on the Jadgāls.

6 The remaining contributions have a linguistic focus. Habib Borjian gives a detailed account of the dialect of Khur (a town between Yazd, Semnan and Mashhad in the Dasht-e Kavir). There are four lexical studies. Matteo De Chiara's article analyses the names of the seasons, months and weekdays in the Pashto dialect of the Swāt district in Pakistan. The role of Pashto as a source or intermediary of borrowings in Dardic languages is investigated by Sebastian Heine ( 26 words + kinship terms +2 verbs). Ela Filippone gives a detailed survey of the denomination of 'gums' in Iranic languages as part of a broader onomasiological project on body part terms. Adriano V. Rossi presents an etymological account of the Brahui word gōrom 'herd' with a map at the very end of the book that displays the distribution of this word in Afghanistan (taken from the Atlas linguistique de l'Afghanistan materials kept at the University of Bern).

7 Vincent Hachard's contribution contains an introduction of 20 pages to the study of alignment in general ("configurations actancielles") followed by case studies on New Persian, Sorani-Kurdish and Mundji. This topic is continued by Daniel Septfonds with an investigation of the alignment system in Ormuri. Both studies are descriptive, which has results in the interpretation of morphological differences like differential object marking being considered as indications of a different structure (e.g. neutral, accusative, disjunct).

8 Jeremy Hawbaker and Joan L. G. Baart investigate the system of personal-directional prefixes in Logar Ormuri and compare them to their counterparts in Pashto. These are elements prefixed to the verb, which usually agree in person with another participant.

Lutz Rzehak analyses modal constructions in Pashto that express ability, capability and permission. Beside an inherited structure, Rzehak identifies three constructions that are gradually more similar to the Dari counterpart suggesting contact-induced change in the expression of this category. The paper concludes with an outlook on the situation in Balochi. 


\section{AUTHORS}

THOMAS JÜGEL

Allemagne 